\title{
Seasonal Food Preferences of Cattle on Native Range in the South Texas Plains
}

\author{
J.H. EVERITT, C.L. GONZALEZ, G. SCOTT, AND B.E. DAHL
}

\begin{abstract}
Cattle diets were studied on a predominantly native range in Hidalgo County, which is in the extreme southern part of Texas, from September, 1976, to November, 1977. Microhistological examination of cattle feces was used to determine the botanical composition of diets. Percentages of grasses, forbs, and browse consumed by cattle for the fall of 1976 and the winter, spring, summer, and fall of 1977 , respectively, were: grasses $-77.9,81.2$, 84.9, 65.1, 63.6; forbs $-20.2 ; 6.9,13.4,31.6,34.8$; and browse -2.0 , 11.9, 1.7, 3.3, 1.6. Cattle showed an increasing preference for forbs during the summer and fall of 1977 as the availability of several grass species decreased. Roemer three-awn, red lovegrass, and hooded windmillgrass were the most utilized species, but they were eaten in about equal proportion to their availability. Buffelgrass, common Bermudagrass, and sedges were eaten in lesser amounts but were highly preferred. Perennial forbs, especially spreading sida and orange zexmenia were important components of the summer and fall diets. Pricklypear was the only important browse species which was important only in winter. These data indicated that perennial grasses made up the bulk of cattle diets on a predominantly native range in south Texas; however, perennial forbs were important seasonally.
\end{abstract}

Authors are range scientists, U.S. Department of Agriculture, Science and Education Administration, Agricultural Research, Weslaco, Texas, and research technician and professor, Department of Range and Wildlife Management, Texas Tech University, Lubbock, Texas.

This study is a contribution from U.S. Dep. Agr. Sci. and Educ. Admin., Agr. Res., Soil and Water Conserv. Res., Weslaco. Texas, and College of Agr. Sci., Texas Tech Univ., Lubbock.

We thank Raul Tijerina, Jr., and the late J.O. Molina and his wife Gloria, for their support and cooperation during this study. The authors also acknowledge the help of G.V. Latigo and M.A. Alaniz, Weslaco, Texas, for data analyses.

Manuscript received January 23, 1980.
The South Texas Plains cover more than 8 million ha, most of which in grazing lands (Gould 1975). The relatively mild winters of this area allow the ranges to be grazed all year. A knowledge of the plant species grazed by cattle and the species preferred during the various seasons could be used to enhance the management of these ranges.

Little information is available concerning the botanical composition of cattle diets in the South Texas Plains. Davis (1952) studied the year-long diet of steers on the live oak-mesquite ranges of south Texas, but this area is in a transition zone between the South Texas Plains and Coastal Prairies and is more typical of the latter (Gould 1975). Our objective was to determine the seasonal diets and food preferences of cattle grazing a predominantly native range in extreme southern Texas.

\section{Study Area and Methods}

This study was conducted on the 1,250-ha Tijerina Ranch, $40 \mathrm{~km}$ northwest of Edinburg, Hidalgo County, in the extreme southern portion of the South Texas Plains. This area's climate is mild. Winters are short and temperatures relatively warm throughout the year. The average length of the growing season is 305 days (USDC 1970). Summer temperatures and evaporation rates are high. The average annual rainfall is $49 \mathrm{~cm}$. Average rainfall is lowest in January and February and highest in May or June and September. Long rainless periods are common anytime of the year. The rainfall distribution for 1976 and 1977 is presented in Figure 1. Total precipitation was 81.0 and $37.9 \mathrm{~cm}$ for 1976 and 1977, respectively.

The topography is flat to gently sloping. Two range sites and two soil types occur on the Tijerina Ranch. The major range site is the 


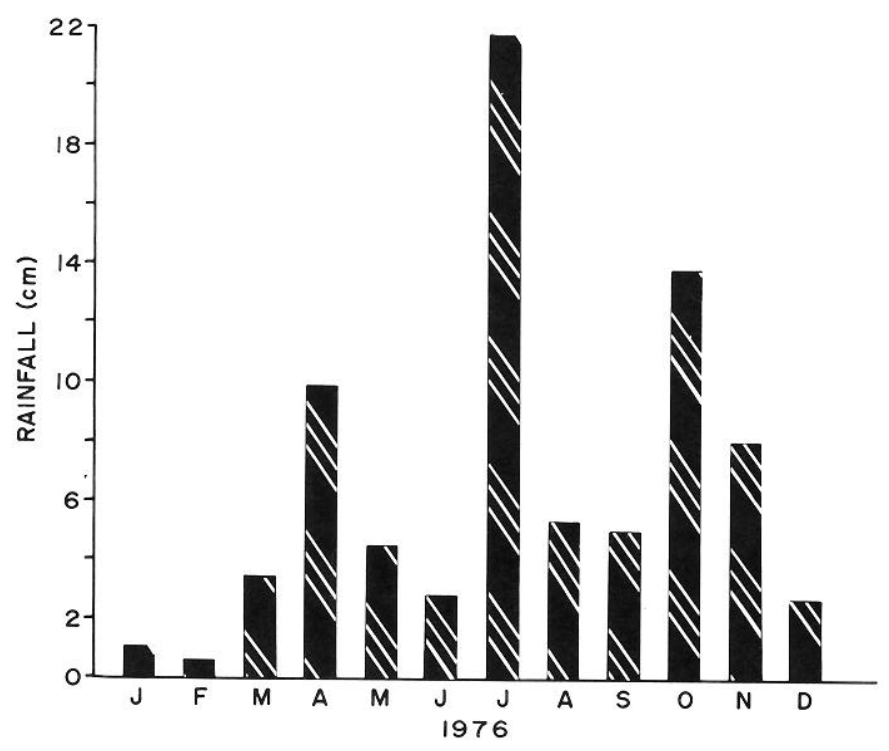

roemeriana), fringed signalgrass (Brachiaria ciliatissima, red lovegrass (Eragrostis oxylepis), and slender grama (Bouteloua repens). Numerous species of perennial and annual forbs also occur. Several small strips of native brush have been bulldozed and seeded to buffelgrass (Cenchrus ciliaris), an introduced grass species. Buffelgrass has also invaded some of the native areas.

The second range site on the area is the clay loam, which is made up of Rio soils (Typic Argioquolls). It occurs in depressions ranging from 0.5 to 3 ha. These depressions serve as catchments for runoff from the surrounding terrain and are often partially inundated. Although they are dispersed throughout the study area, they make up less than $5 \%$ of the total land area. The plant community is dominated by a variety of grasses, sedges, and forbs.

The major land use on the Tijeriana Ranch is primarily a cowcalf ranching operation. Our study was conducted on a 600-ha predominantly native pasture that was continuously grazed by 90 to 100 mother cows of the Santa Gertrudis cattle breed. The pasture was in a mid- to high-poor range condition.

Available forage for cattle was determined by clipping all herbaceous vegetation at ground level in 20 randomly selected quadrats each $50 \times 50 \mathrm{~cm}$ (Stewart and Hutchins 1936). The clippings were sorted and sacked by species, and the dry weights were determined after oven drying for $48 \mathrm{hr}$ at $65^{\circ} \mathrm{C}$. Vegetation was sampled every 4 to 6 weeks. Vegetational sampling sites were selected at random within the pasture. The density and species composition of woody plants and cacti were determined by the point-centered quarter method (Dix 1961).

A microhistological examination of cattle feces was used to determine diets of cattle. We collected six fecal samples at 3 to 4 week intervals from September 1976 till November 1977. Samples were randomly collected from throughout the pasture. Sample areas varied from 10 to 20 hectares and each sample was a composite of 10 subsamples. A subsample of feces weighing about 2 grams was taken from each cow defecation. Duplicate slides were prepared from each sample according to methods outlined by Sparks and Malechek (1968), Ward (1970), and Flinders and Hansen (1972). Ten fields per slide were examined at $100 \times$ to estimate the relative frequency of food items in cattle diets (Free et al. 1971; Hansen and Reed 1975). Frequency percentages for each species were converted to particle density per field using the tabular values of Fracker and Brishle (1944). Particle density was then expressed as relative density for each species (Sparks and Malechek 1968). Individual food items were identified by comparing histological features identified in fecal fragments to a reference slide collection prepared from plants collected on the study area (Davies 1959; Brusven and Mulkern 1960; Storr 1961).

Both food habits and available forage data were summarized by seasons as follow: spring (March-May); summer (June-August); fall (September-November); and winter (December-February).

Preference ratings were calculated for the major species in the diet during the different seasons of the year using the method described by Durham and Kothmann (1977):

$$
\text { Preference rating }=\frac{\% \text { in diet }-\% \text { available }}{\% \text { in diet }+\% \text { available }} \times 10
$$

A preference rating of +10 indicated a high preference, whereas -10 indicated a low preference. A preference rating of 0 represented selection in proportion to availability.

\section{Results and Discussion}

\section{Forage Availability}

Total forage available to grazing animals in the fall of 1976 and the winter, spring, and summer, and fall of 1977, respectively, was: $902,583,791,647$ and $540 \mathrm{~kg} /$ ha. Differences in forage availability between the two fall periods were probably the result of drier conditions during 1977 (Fig. 1) and continued grazing. The proportions of grasses and forbs changed markedly among seasons (Fig. 3). Forb composition was highest in summer and lowest in winter, whereas grass composition was highest in winter and lowest

Fig. 2. The red sandy loam range site on the Tijerina Ranch in south Texas. 


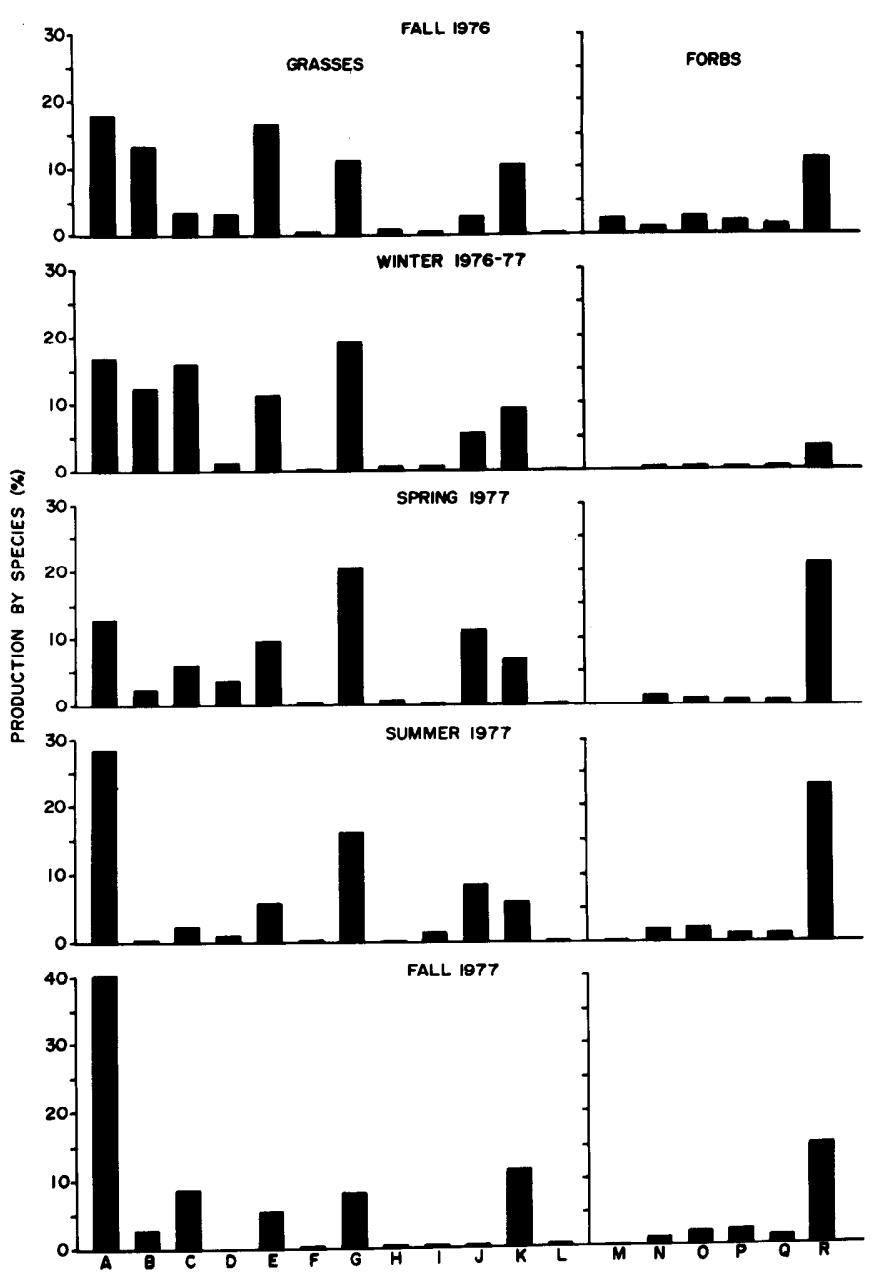

Fig. 3. Seasonal herbaceous species composition of plants available to cattle on the Tijerina Ranch in south Texas. Species are Roemer threeawn (A), slender grama (B), Fringed signalgrass (C), buffelgrass (D), hooded windmillgrass $(E)$, common Bermudagrass $(F)$, red lovegrass $(G)$, knotroot panicum $(H)$, Hall's panicum $(I)$, fringeleaf paspalum $(J)$, other grasses $(K)$, sedges $(L)$, false mallow $(M)$, bracted sida $(N)$, spreading sida $(O)$, wild chocolate $(P)$, orange zexmenia $(Q)$, and other forbs $(R)$. Other grasses and other forbs were those species unimportant to cattle diets.

in summer. A variety of grasses and forbs were available. Major differences were noted among individual species composition in the rates of forage disappearance and accumulation. Roemer three-awn was the most abundant grass on the study area. Its availability more than doubled from the fall of 1976 to the fall of 1977. Red lovegrass was the second most abundant grass-it was most abundant during the winter and spring. Other major grasses were hooded windmillgrass, fringed signalgrass, and slender grama. The availability of hooded windmillgrass, slender grama, and buffelgrass decreased markedly in the fall of 1977 as compared with the fall of 1976.

Woolly croton (Croton capitatus) and sleep daisy (Xanthisma texana), both annuals, were the most abundant forbs during the summer and fall. Major perennial forbs which were available throughout the year were spreading sida (Sida filicaulis), bracted sida (Sida ciliaris), and wild chocolate (Waltheria indica) (Fig. 3).

A variety of woody plants and cacti were available for grazing a nimals (Table 1). Woody plant and cactus density averaged 1,468 plants/ha with 12 species making up the major portion.

\section{Botanical Composition of Diets}

The year-round diet of cattle was comprised of $74.7 \%$ grasses, $21.3 \%$ forbs, and 4.0 browse (Table 2). Proportions of grasses,
Table 1. Density (plants/ha) of woody plant and cactus species available to cattle on the Tijerina Ranch in south Texas.

\begin{tabular}{llc}
\hline \hline Scientific name & Common name & $\begin{array}{c}\text { Density } \\
\text { (plants/ha) }\end{array}$ \\
\hline Jatropha dioica & Leatherstem & 201 \\
Zanthoxylum fagara & Lime pricklyash & 161 \\
Opuntia lindheimeri & Pricklypear cactus & 154 \\
Prosopis glandulosa & Mesquite & 139 \\
Eysenhardtia texana & Texas kidneywood & 109 \\
Acacia rigidula & Blackbrush & 97 \\
Colubrina texensis & Hogplum & 72 \\
Condalia hookeri & Bluewood & 69 \\
Opuntia leptocaulis & Tasajillo & 67 \\
Acacia greggii & Catclaw & 67 \\
Lycium berlandieri & Wolfberry & 45 \\
Celtis pallida & Granjeno & 37 \\
\multicolumn{1}{c}{ Total major spp. } & & 1218 \\
Miscellaneous spp. & & 250 \\
\multicolumn{1}{c}{ Total spp. } & & \\
\hline
\end{tabular}

'Plant names are according to Correll and Johnston (1970).

forbs, and browse changed greatly among seasons. Grass content of the diet was lowest in the fall of 1977 and highest in spring. Forb content of the diet ranged from a high of $34.8 \%$ in the fall of 1977 to a low of $6.9 \%$ during the winter. Browse was important only in winter. Monthly fluctuations in the various portions of the forage classes in the diet are shown in Figure 4. The differences in grass and forb consumption between the fall periods of 1976 and 1977 were attributed to major differences in availability of grasses (Fig. 3 ). Evidently a marked reduction in the amounts of several grass species available in the fall of 1977 caused cattle to consume more forbs.

Fifty-seven species of plants were recorded in the cattle diet including 22 grasses, 30 forbs, and 5 browse. This agreed with the findings of Springfield and Reynolds (1951), Herbel and Nelson (1966), and Beck (1975), who found that cattle selected from a variety of plants when given free choice. However of the 57 species, 18 species made up the bulk of the cattle diet (Table 2).

Roemer three-awn made up the largest portion of the year-long diet (Table 2). It became increasingly important as the study progressed and made up $25.9 \%$ of the diet during the fall of 1977 . Although it was consumed in large amounts, its preference values indicated that it was slightly negative in preference or selected in proportion to its availability (Table 3).

Red lovegrass was the second most important species in the diet and the most important plant in the spring. It was generally

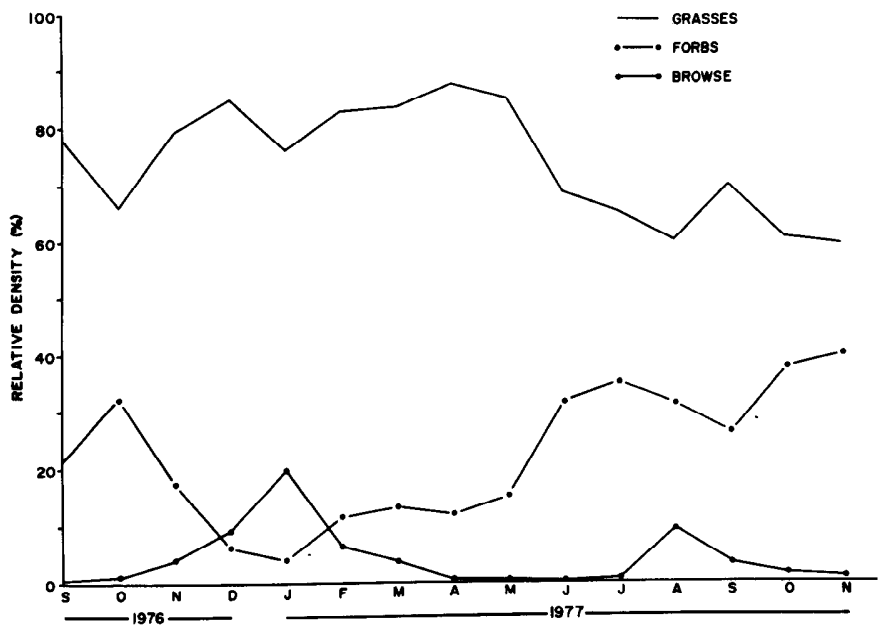

Fig. 4. Monthly fluctuations of grasses, forbs, and browse in the diet of cattle on the Tijerina Ranch in south Texas. 
Table 2. Average seasonal botanical composition of plant species $(\% \pm \mathrm{SE})$ in cattle diets on the Tijerina Ranch in south Texas.

\begin{tabular}{|c|c|c|c|c|c|c|c|}
\hline \multirow{2}{*}{$\frac{\text { Scientific name }}{\text { Grasses (includes sedges) }}$} & \multirow[t]{2}{*}{ Common name } & \multirow[t]{2}{*}{ Fall 1976} & \multirow[t]{2}{*}{ Winter 1977} & \multirow[t]{2}{*}{ Spring 1977} & \multicolumn{2}{|c|}{ Summer 1977Fall 1977} & \multirow[t]{2}{*}{ Average } \\
\hline & & & & & & & \\
\hline $\begin{array}{l}\text { Aristida roemeriana } \\
\text { Bouteloua repens } \\
\text { Brachiaria ciliatissima } \\
\text { Cenchrus ciliaris } \\
\text { Chloris cucullata } \\
\text { Cynodon dactylon } \\
\text { Eragrostis oxylepis } \\
\text { Panicum firmulum } \\
\text { Panicum hallii } \\
\text { Paspalum setaceum } \\
\text { Cyperus spp. }\end{array}$ & $\begin{array}{l}\text { Roemer three-awn } \\
\text { Slender grama } \\
\text { Fringed signalgrass } \\
\text { Buffelgrass } \\
\text { Hooded windmillgrass } \\
\text { Common Bermudagrass } \\
\text { Red lovegrass } \\
\text { Knotroot panicum } \\
\text { Halls panicum } \\
\text { Fringeleaf paspalum } \\
\text { Sedges }\end{array}$ & $\begin{array}{r}10.5 \pm 1.3 \\
9.8 \pm 0.5 \\
4.5 \pm 1.4 \\
9.3 \pm 1.8 \\
8.9 \pm 2.7 \\
5.4 \pm 1.1 \\
11.8 \pm 1.4 \\
5.2 \pm 0.7 \\
4.7 \pm 0.7 \\
3.0 \pm 0.9 \\
2.8 \pm 0.8\end{array}$ & $\begin{array}{r}10.3 \pm 1.5 \\
5.9 \pm 1.4 \\
2.5 \pm 0.3 \\
9.0 \pm 1.5 \\
14.0 \pm 2.0 \\
5.2 \pm 1.2 \\
13.4 \pm 1.2 \\
1.7 \pm 0.5 \\
4.7 \pm 0.9 \\
1.8 \pm 0.6 \\
7.9 \pm 2.4\end{array}$ & $\begin{array}{r}13.3 \pm 1.8 \\
8.5 \pm 1.9 \\
2.9 \pm 0.7 \\
8.6 \pm 0.5 \\
14.7 \pm 0.5 \\
4.4 \pm 1.3 \\
19.0 \pm 1.2 \\
1.1 \pm 0.4 \\
8.0 \pm 2.1 \\
-\quad- \\
1.4 \pm 0.2\end{array}$ & $\begin{array}{r}15.8 \pm 2.4 \\
4.2 \pm 1.5 \\
-\quad- \\
2.5 \pm 1.4 \\
10.6 \pm 3.4 \\
7.4 \pm 2.0 \\
8.1 \pm 2.6 \\
2.4 \pm 0.4 \\
4.5 \pm 1.9 \\
- \\
2.2 \pm 2.2\end{array}$ & $\begin{array}{l}25.9 \pm 2.0 \\
3.1 \pm 1.5 \\
3.0 \pm 1.9 \\
-\quad- \\
8.1 \pm 1.6 \\
5.6 \pm 1.3 \\
5.7 \pm 0.6 \\
-\quad- \\
1.4 \pm 1.2 \\
-\quad- \\
5.8 \pm 1.6\end{array}$ & $\begin{array}{r}15.2 \\
6.3 \\
2.6 \\
5.9 \\
11.2 \\
5.6 \\
11.6 \\
2.1 \\
4.7 \\
1.0 \\
4.0\end{array}$ \\
\hline $\begin{array}{r}\text { Others }^{2} \\
\text { Total }\end{array}$ & & $\begin{array}{r}2.0 \quad- \\
77.9\end{array}$ & $\begin{array}{r}4.8- \\
81.2\end{array}$ & $\begin{array}{r}3.2- \\
84.9\end{array}$ & $\begin{array}{r}7.4- \\
65.1\end{array}$ & $\begin{array}{r}5.0- \\
63.6\end{array}$ & $\begin{array}{r}4.5 \\
74.7\end{array}$ \\
\hline Forbs & & & & & & & \\
\hline $\begin{array}{l}\text { Malvastrum } \\
\quad \text { coromandelianum } \\
\text { Sida ciliaris } \\
\text { Sida filicaulis } \\
\text { Waltheria indica } \\
\text { Zexmenia hispida } \\
\text { Others } \\
\text { Total }\end{array}$ & $\begin{array}{l}\text { False mallow } \\
\text { Bracted sida } \\
\text { Spreading sida } \\
\text { Wild chocolate } \\
\text { Orange zexmenia }\end{array}$ & $\begin{array}{l}3.4 \pm 0.6 \\
1.0 \pm 0.7 \\
4.5 \pm 0.5 \\
3.3 \pm 1.1 \\
3.8 \pm 0.8 \\
4.1 \\
20.1\end{array}$ & $\begin{array}{ll}- & - \\
- & - \\
2.1 \pm 0.7 \\
1.3 \pm & 1.1 \\
1.3 \pm & 0.1 \\
2.2 & \\
6.9\end{array}$ & $\begin{array}{r}- \\
1.2 \pm 0.5 \\
3.1 \pm 0.9 \\
1.4 \pm 0.4 \\
1.6 \pm 0.6 \\
6.0 \\
13.4\end{array}$ & $\begin{array}{l}1.3 \pm 0.6 \\
2.7 \pm 0.9 \\
9.4 \pm 1.6 \\
1.0 \pm 0.8 \\
8.1 \pm 1.8 \\
9.1 \\
31.6\end{array}$ & $\begin{array}{r}2.8 \pm 0.9 \\
2.3 \pm 0.5 \\
10.0 \pm 1.7 \\
1.2 \pm 0.6 \\
11.7 \pm 1.3 \\
6.8 \\
34.8\end{array}$ & $\begin{array}{r}1.5 \\
1.4 \\
5.8 \\
1.6 \\
5.3 \\
5.7 \\
21.3\end{array}$ \\
\hline $\begin{array}{l}\text { Browse } \\
\text { Opuntia lindheimeri } \\
\text { Prosopis glandulosa- } \\
\text { fruit } \\
\text { Others } \\
\text { Total }\end{array}$ & Pricklypear & $1.8 \pm 1.0$ & $\begin{array}{l}10.0 \pm 2.6 \\
- \\
1.9 \\
11.9\end{array}$ & $\begin{array}{l}1.5 \pm 0.8 \\
-\quad- \\
0.2 \\
1.7\end{array}$ & $\begin{array}{l}2.2 \pm 2.1 \\
1.1 \pm 0.7 \\
- \\
3.3\end{array}$ & $\begin{array}{l}1.2 \pm 0.5 \\
-\quad- \\
0.4 \\
1.6\end{array}$ & $\begin{array}{l}0.2 \\
0.5 \\
4.0\end{array}$ \\
\hline
\end{tabular}

'Plant names are according to Correll and Johnston (1970).

2"Others" includes plant species that comprised less than $1 \%$ of the cattle diets.

selected in proportion to its availability (Table 3 ). Hooded windmillgrass was the third most important plant and the most utilized species in winter. Its preference values indicated that it was generally selected in proportion to its availability.

Buffelgrass and common Bermudagrass (Cynodon dactylon) were preferred species. Buffelgrass comprised a major portion of the diet in the fall of 1976 and in the winter and spring of 1977. A decline in the availability of buffelgrass (Fig. 3) in the summer of 1977 was reflected in a large decrease in consumption at this time.
By the fall of 1977 buffelgrass was not recorded in the available herbage or diet. Common Bermudagrass was a relatively scarce species on the ranch and was most abundant on the small clay loam sites. Cattle were often observed grazing on these areas.

Sedges were highly preferred throughout the study and comprised $4.0 \%$ of the year-round diet. They were scarce on the study area; the largest concentrations were on the clay loam sites.

The most important forbs were spreading sida and orange zexmenia (Zexmenia hispida). Both species were eaten throughout the

Table 3. Relative preference values for major herbaceous plant species in the seasonal diet of cattle on the Tijerina Ranch in south Texas.

\begin{tabular}{|c|c|c|c|c|c|}
\hline Species & $\begin{array}{l}\text { Fall } \\
1976\end{array}$ & $\begin{array}{r}\text { Winter } \\
1976-77\end{array}$ & $\begin{array}{r}\text { Spring } \\
1977\end{array}$ & $\begin{array}{r}\text { Summer } \\
1977\end{array}$ & $\begin{array}{r}\text { Fall } \\
1977\end{array}$ \\
\hline \multicolumn{6}{|l|}{ Grasses (includes sedges) } \\
\hline $\begin{array}{l}\text { Roemer three-awn } \\
\text { Slender grama } \\
\text { Fringed signalgrass } \\
\text { Buffelgrass } \\
\text { Hooded windmillgrass } \\
\text { Common Bermudagrass } \\
\text { Red lovegrass } \\
\text { Knotroot panicum } \\
\text { Halls panicum } \\
\text { Fringeleaf paspalum } \\
\text { Sedges }\end{array}$ & $\begin{array}{r}-2.6 \\
-1.5 \\
1.6 \\
5.1 \\
-2.9 \\
8.3 \\
0.3 \\
7.3 \\
8.1 \\
0.7 \\
8.7\end{array}$ & $\begin{array}{r}-2.4 \\
-3.5 \\
-7.2 \\
7.5 \\
1.0 \\
9.3 \\
9.8 \\
-1.8 \\
3.1 \\
6.8 \\
-5.0 \\
9.8\end{array}$ & $\begin{array}{r}0.2 \\
5.6 \\
-3.5 \\
4.0 \\
2.1 \\
8.3 \\
-0.3 \\
1.0 \\
9.5 \\
- \\
5.6\end{array}$ & $\begin{array}{r}-2.9 \\
8.3 \\
- \\
4.3 \\
2.8 \\
9.5 \\
-3.4 \\
9.2 \\
5.3 \\
- \\
8.3\end{array}$ & $\begin{array}{r}-2.2 \\
0.7 \\
-4.8 \\
- \\
2.0 \\
9.0 \\
-1.8 \\
- \\
5.6 \\
- \\
8.4\end{array}$ \\
\hline \multicolumn{6}{|l|}{ Forbs } \\
\hline $\begin{array}{l}\text { False mallow } \\
\text { Bracted sida } \\
\text { Spreading sida } \\
\text { Wild chocolate } \\
\text { Orange zexmenia }\end{array}$ & $\begin{array}{r}2.1 \\
0 \\
2.9 \\
2.9 \\
4.6\end{array}$ & $\begin{array}{l}- \\
- \\
6.2 \\
4.4 \\
4.4\end{array}$ & $\begin{array}{r}- \\
-0.8 \\
5.1 \\
1.6 \\
4.1\end{array}$ & $\begin{array}{r}7.3 \\
1.7 \\
6.3 \\
0 \\
7.6\end{array}$ & $\begin{array}{r}9.3 \\
2.8 \\
6.4 \\
-3.1 \\
7.9\end{array}$ \\
\hline
\end{tabular}


study but became increasingly important during the summer and fall of 1977. Together they made up $17.5 \%$ of the summer diet and $21.7 \%$ of the 1977 fall diet. Cattle increasingly preferred these two forbs as the availability of buffelgrass and several other grass species decreased (Fig. 3 and Table 3 ).

Pricklypear cactus was the most important browse species eaten and made up $3.2 \%$ of the year-round diet. It was most important during the winter when it comprised $10.0 \%$ of the diet. Mesquite pods were the only other browse of importance in the diet. They comprised $1.1 \%$ of the summer diet. Other than pricklypear and mesquite pods, cattle used browse very little, even though a large variety of browse species was available.

\section{Conclusions}

These data indicated that perennial grasses make up the bulk of cattle diets on predominantly native range in south Texas; however, perennial forbs are important seasonally and may constitute a significant portion of the diet. Browse was important only during winter. Cattle showed an increasing preference for forbs as several species of grasses decreased in availability. The most abundant species furnished the bulk of diets, although they seemed to be neither preferred nor avoided. Several of the less abundant species were highly selected. These findings support those reported by Van Dyne and Heady (1965). Data from our study would be applicable to a red sandy loam range site in poor condition. A good pasture rotation system which would give the lesser abundant but highly selected species enough time to produce more forage is highly suggested.

\section{Literature Cited}

Beck, R.F. 1975. Steer diets in southeastern Colorado. J. Range Manage. 28:48-51

Brusven, M.A., and B.M. Mulkern. 1960. The use of epidermal characteristics for the identification of plants recovered in fragmentary condition from crops of grasshoppers. North Dakota Agr. Exp. Sta. Res. Rep. 3. 11 p.
Correll, D.S., and M.C. Johnston. 1970. Manual of the vascular plants of Texas. Texas Res. Found. Renner, Texas. 1881 p.

Davies, I. 1959. The use of epidermal characteristics for the identification of grasses in the leafy stage. J. Brit. Grassland Soc. 14:7-16.

Davis, R.B. 1952. The use of rumen contents data in a study of deer-cattle competition and "animal equivalence." Trans. N. Amer. Wildl. Conf. 17:448-458.

Dix, R.L. 1961. An application of the point-centered quarter method to the sampling of grassland vegetation. J. Range Manage. 14:63-69.

Durham, A.J., Jr., and M.M. Kothmann. 1977. Forage availability and cattle diets on the Texas Coastal Prairie. J. Range Manage. 30:103-106.

Flinders, J.T., and R.M. Hansen. 1972. Diets and habitats of jackrabbits in northeastern Colorado. Range Science Dep. Sci. Ser. No. 12. Colorado State Univ., Fort Collins. 29 p.

Fracker, S.B., and J.A. Brischle. 1944. Measuring the local distribution of Ribes. Ecology. 25:283-303.

Free, J.C., P.L. Sims, and R.M. Hansen. 1971. Methods of estimating dry weight composition in diets of steers. J. Animal Sci. 32:1003-1007.

Gould, F.W. 1975. Texas plants-A checklist and ecological summary. Texas Agr. Exp. Sta., Texas A\&M Univ., College Station. MP-585. 121 p.

Hansen, R.M., and L.D. Reid. 1975. Diet overlap of deer, elk, and cattle in southern Colorado. J. Range Manage. 28:43-47.

Herbel, C.H., and A.B. Nelson. 1966. Species preferences of Hereford and Santa Gertrudis cattle on a southern New Mexico Range. J. Range Manage. 19:177-181.

Sparks, D.R., and J.C. Malechek. 1968. Estimating percentage dry weight in diets using a microscopic techniquc. J. Range Manage. 21:264-265.

Springfield, H.W., and H.G. Reynolds. 1951. Grazing preferences of cattle for certain reseeding grasses. J. Range Manage. 4:83-87.

Stewart, G., and S.S. Hutchins. 1936. The point observation-plot (Square foot density) method of vegetation survey. Amer. Soc. Agron. J. 28:714726.

Storr, G.M. 1961. Microscopic analysis of feces, a technique for ascertaining the diet of herbivorous mammals. Aust. J. Bio. Sci. 14:157-164.

United States Department of Commerce. 1970. Climatological summary. Brownsville, Texas. $46 \mathrm{p}$.

Van Dyne, G.M., and H.F. Heady. 1965. Botanical composition of sheep and cattle diets on a mature annual range. Hilgardia. 36:465-492.

Ward, A.L. 1970. Stomach content and fecal analysis: Methods of forage identification. In: Range and wildlife habitat evaluation-A research symposium, U.S. Dep. Agr. Misc. Pub. 1147:146-158.

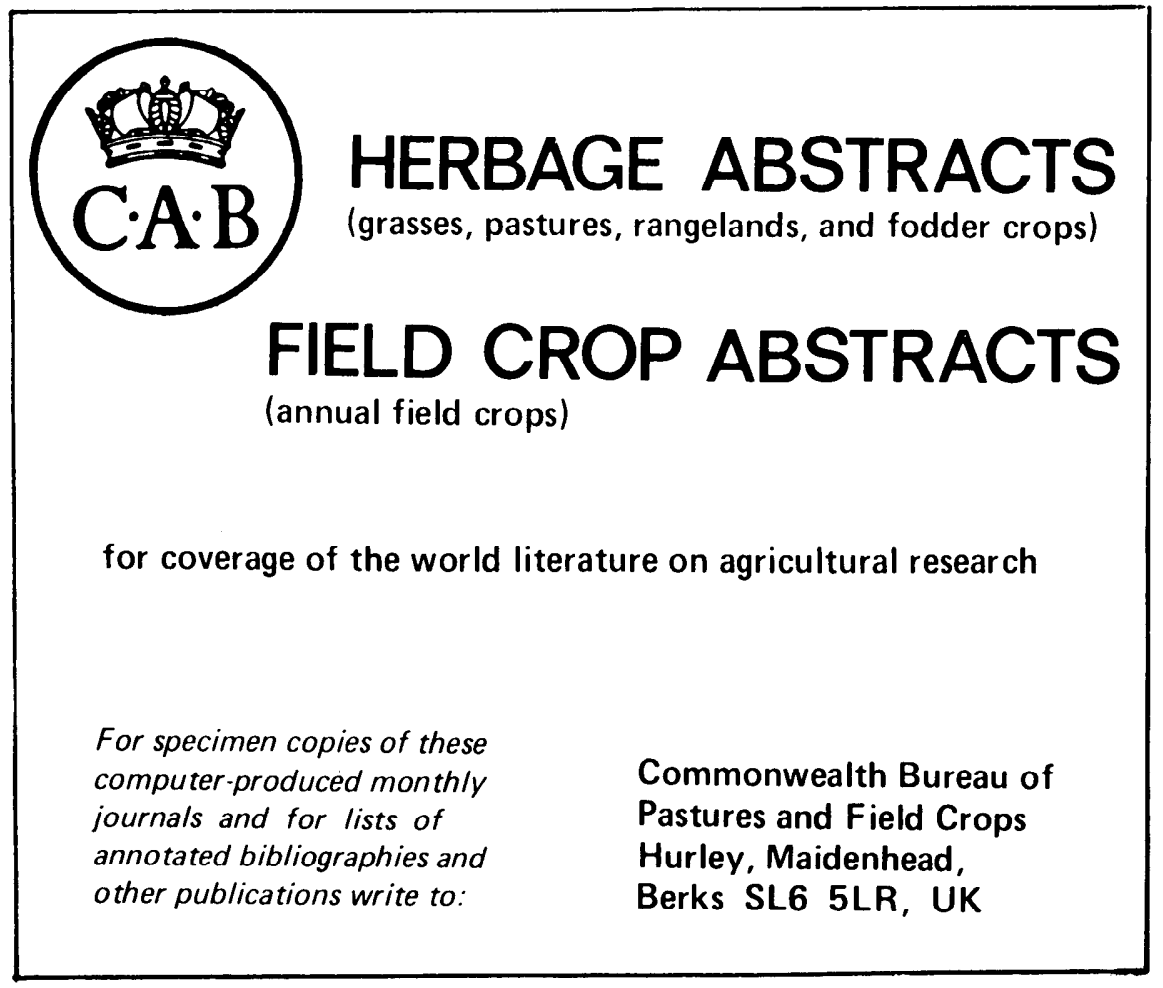

